\title{
The Genealogy of News
}

\author{
Researching Journalistic Food-Chains
}

\author{
ANKER BRINK Lund
}

The number of original journalism studies is growing slowly in spite of the fact that this field of research may indeed offer valuable insights into matters neglected by traditional mass media researchers. The limited amount of studies closely related to practical journalism is primarily due to scepticism among practitioners of the trade. Journalists resent being researched, and the understandable resentment makes data collection difficult for researchers

Consequently, we know quite a lot about news contents and audience reactions towards media products. But aside from the individualistic gatekeeper research, few studies have focused on the production of news in a genealogical perspective answering fundamental questions concerning who produce original news, and how journalists collectively set the agenda for the ongoing process of news production. ${ }^{1}$

Denmark as a relatively small country with a limited amount of news providers and relatively few professional journalists makes it possible to answer such questions at a comprehensive level, i.e. covering all national news media and their interrelations. No such effort, however, has been attempted until 1999 in spite of the fact that media research in the Scandinavian countries have a long tradition for content analysis of selected media conducted within a comparative framework (e.g. Andersen et al., 1977; Bakke \& Siune, 1972; Becker et al, 1996; Hjarvard, 1999; Sand \& Helland, 1998; Søllinge, 1999). Scandinavian and Finnish research has also contributed to the understanding of globalization of news contributing to transnational, comparative studies (e.g. Boyd-Barett \&

University of Southern Denmark, Campusvej 55, DK-5230 Odense, abl@journalism.sdu.dk
Rantanen, 1998; Bruhn Jensen, 1998). One Swedish study offer a more comprehensive data base covering most national media at one specific day (Nordstedt, 1994), and one project has researched a week of news in selected media over time (Ekecrantz \& Olsson, 1994). But a current, comprehensive, and across-the-board analysis of media content nation-wide over a full week has never before been reported.

A grant from the Danish Parliament (Magtudredningen: An Analysis of Democracy and Power in Denmark) has enabled us to cover all national, regional and local news media excluding trade papers and magazines. Given a tally of all news items, input to and output from the national news agency (Ritzaus Bureau), plus comments from the journalistic shop-floor gathered by interviews and observation (ad modus Elliott, 1972), we may consequently venture to answer the basic question of journalism studies: who lives on whom in journalistic food-chains?

Content analysis of one November week, 1999, has been conducted. Methodically the research is founded in Lund (1997 \& 1999) and project design inspired by Ekecrantz \& Olsson, 1990; Høyer, 1982; Petersson \& Carlberg, 1990. From Monday the $15^{\text {th }}$ till Sunday the $21^{\text {st }}$ all news items from 33 daily newspapers, the two public service television stations, the national radio station, eight local radio stations, and nine regional $\mathrm{TV}$-stations have been counted and coded. Supplementing the content analysis (30,798 items) we conducted telephone interviews $(1,005$ respondents) with a representative sample of the Danish population Based upon this data the research project - One Week of Danish News - is intended to inform the heated debate about competing news efforts originating from press, radio and TV. 


\section{Overrated TV News}

Our survey data indicate that TV comes out on top of the list when media consumers are asked to assess news transmission. The survey was designed to allow respondents to name several sources of current events. 58\% said that they had their most important news items from TV, and $41 \%$ of these said it was from the two national public service TV channels. The daily newspapers taken together was named as a primary source by $32 \%$. The national radio news programme, Radioavisen, together with the regional radio programmes scored $14 \%$. In spite of great expectations in relation to the Internet, only $0.7 \%$ of Danes gave this as their most important source in terms of current events.

There is nothing new in TV coming out on top. But the design of the research project makes it feasible to check the respondents' answers against the factual content of the various media. This test reveals that a substantial number, one fifth of the events that respondents thought they had seen on $\mathrm{TV}$, had in fact never been so transmitted. Respondents remember wrongly and in so doing overestimate TV as a news medium.

Danish TV stations do convey to the public the impression that TV is the leading purveyor of news. This is an impressive feat when we can demonstrate that the daily offering from the news programmes of the two national TV channels (DRI and TV2) in total comprises less than half of the daily news production of an average morning paper. If we add on the other electronic media, TV and ra- dio contribute just under $8 \%$ of the total Danish news production.

The daily newspapers deliver $88 \%$ of the news production in the course of a news week. Note also that this is the original performance, as we have excluded the recycling, borrowings, special supplements, listings and debate items. This net figure also does not comprise common material from the national news agency, Ritzaus Bureau, that accounts for $4 \%$ of total news production. That may not sound like a lot, but Ritzau gives gross production a much bigger impact, as news agency releases are recycled (with or without disclosure of the source) by the other newsmedia.

News production in trade journals and magazines is not included in the figures due to limitations in project design. At a modest estimate these sources contribute a further $5-10 \%$ net. The Internet services on the other hand still live on the scrounge, without much independent contribution to speak of. In round figures, Danish news purveyors all in all provide about one million news items per annum, of which around 800,000 are generated by the daily papers.

\section{Negative Citation Balance}

Local newspapers are the major news purveyors in Denmark. This turns mainly on their dedication to the local vicinity, which nearly always results in 'solo' material - and misère stories at that: because for the most part there are no other media citing or elaborating on this local solo material. So, although

Figure 1. Danish Purveyors of News (net-new, minus recycling) Week 46, 1999

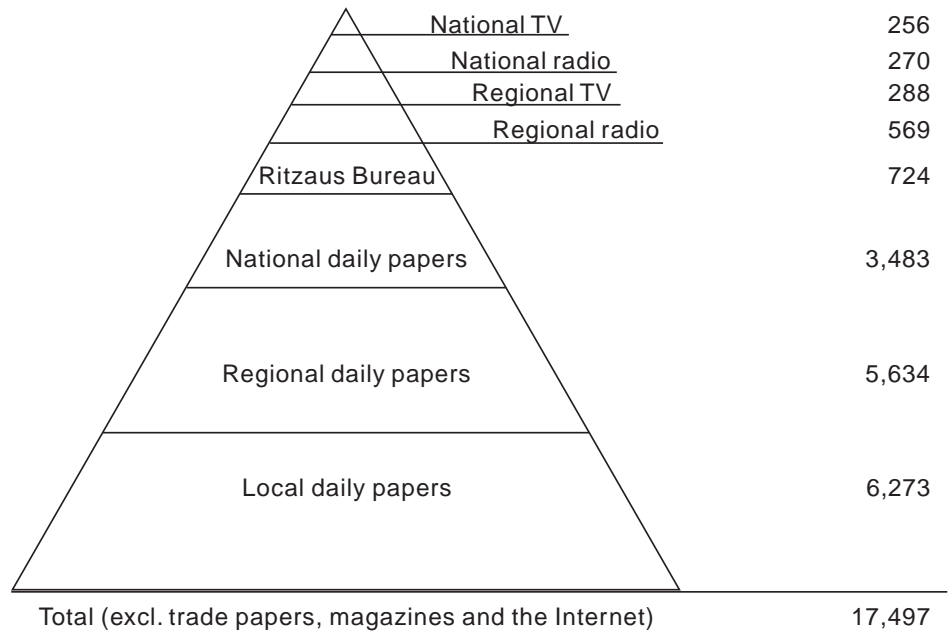


Denmark's 17 local newspapers show impressive productivity, they are not big on the national news scene as a whole. Of the 6,723 original contributions from the local press in our week of news, we found that only 49 stories (duly credited) had been reproduced elsewhere plus 84 further borrowings without quoted sources. This compares with local press borrowings of 1,276 units, leaving local papers all told with a negative citation balance.

Apart from Ritzau, the news agency, only four news media can boast of a positive balance, i.e. they are cited and borrowed from more often than they themselves borrow from others. All four are national morning dailies, and yet, as a whole, even this category consisting of ten news institutions has a negative balance as far as citations go.

If we look at the overall productivity, the six regional dailies come out on top. No other media institutions offer as much original news material as the independent regional papers do. All the same, the regional dailies do have a negative citation balance. In spite of the fact that they act as important sources for regional radio and television stations, this brings no corresponding direct credit. And the negative quotient is bumped up by the fact that the national papers typically ignore the regional papers as potential partners setting the national news agenda. Furthermore, the citation balance also suffers from the fact that the regional dailies cover national and international affairs by drawing heavily on news agency releases.

\section{Underrated Common Material}

Our research produces a clear picture of the interaction between four types of news producers, with the daily newspapers as the main news purveyors and - right at the hub - the news agency owned and run by the daily papers.

The editorial aim of most mass media is that their readers, listeners or viewers should be kept informed of all the major events of the day, and so will need to consult one media source only. Limited financial and time resources mean that not enough professional staff $i$ at hand to cover everything. Consequently, many editorial offices assign the majority of the staff journalists to 10-20 events that are being similarly covered by competing media. Only a minority of the workforce is assigned to develop original news stories.

Poaching and stealing go on nationally, regionally and locally, but Ritzaus Bureau occupies a key position as the place where news is digested and made common property.
If a local or international story does not find its way to Ritzau, it is most likely a dead duck, even though the public may deserve to see it being distributed nationally.

The national news agency estimates that its head office receives one million letters and press releases a year. In the course of our research period, Ritzaus Bureau transmitted, with clear acknowledgement, 75 from Danish newspapers, 18 from specialized journals and magazines, 13 from radio stations and 10 from TV. Add to this count 724 original contributions. The output stimulated 2,240 citations, plus 2,838 uncredited borrowings in which it was not immediately obvious that Ritzau was the chief source.

Without this comprehensive recycling, the journalists' food-chains would rapidly give rise to severe starvation. From the international perspective, Ritzau is particularly indispensable. Danish news providers who have rejected this material comprise only one local newspaper, Bornholms Tidende, regional radio and regional TV. For the remainder, which includes the large national morning papers, the Ritzau news releases provide an indispensable lifeline to the world outside Denmark. For three of the major events og the week - an earthquake in Turkey, the OSCE Summit, and the Egypt Air disaster - practically all the Danish news providers based their coverage on sources mediated by Ritzau and international picture bureaux.

Our content analyses clearly demonstrates that the most reliable way of getting cited in other news media is to go via Ritzau, though we find that institutional sources in the political system and in trade $\&$ industry increasingly prefer to make deals with specific media in order to go solo with a story and offer targeted follow up.

\section{Lemming Syndrome?}

The important question of pack journalism can be more closely examined by studying data from One Week of Danish Journalism. When the research project was launched we were particularly eager to examine possible tendencies towards 'journalistic overdrive' (Hernes, 1978; Petersson \& Carlberg, 1990). We wanted to test the hypothesis - often voiced by media critics - that journalists are akin to the small rodents of the vole family myodes lemmus.

Lemmings have many useful attributes. The claws on their forelegs are elongated and well suited to investigative digging, but as a group the lemmings have a severe defect: now and then they 
run amok. They take off in large swarms, all heading the same way. Although they may meet neckbreaking blind alleys or dangerous descents, they forge heroically ahead over the edge of the abyss, in a kind of mass suggestion that is expressed as a compulsion to follow-the-leaders wherever they go.

As can be seen from the content analyses, our week of news contains many instances of Danish journalists demonstrating a herd mentality. However, in the light of the assembled research data, the lemming hypothesis has to be modified. Many journalists have argued with some justification that the monotony of the various modern media is simply an expression of professional routines and ideals of objectivity. And we must admit that there is indeed only limited amounts of reality for journalists to cover.

Setting aside the underrated common material, it would seem that journalists on exceptional occasions only, go into overdrive and run amok. As a rule, professional working standards, typically involving recycling news worthy material, prevail. More important than the lemming syndrome in the day-to-day genealogy of news are the productive interactions of the ideas-chain, the source-chain, and the presentation-chain in the working process of professional journalism.

The ideas-chain contains the basic stuff of journalism, and even in these electronic times the old adage: "No cut, no paste - no journalists!" (Andersen et al, 1977) holds true. Systematic recycling of news without mutual accreditation is apparently accepted as the journalistic norm. But fortunately a rich variety of topics and everyday stories abound. Especially in the printed media, the public is offered a wide array of takes on and insights into Danish morals and habits, without major world events being forgotten.

One exciting research finding in relation to the ideas-chain is a journalistic practice we have called the 'anti-lemming syndrome'. This trait is especially noticeable in morning dailies and among the regional competitors, apparently begrudging and despising each other's headline stories. This causes the competing news rooms to arrive belatedly and awkwardly on the scene of newsworthy serial events. An 'anti-lemming' does not get too involved before a local case has been found or an exclusive interview with an expert source may be conducted.

The source-chain, in this way, can be used to compensate for a shortfall of original ideas. In modern news transmission the more or less autonomous use of sources is not merely an ancillary aid, but from time to time it becomes a practical alternative to journalistic originality when time and manpower are in short supply.

By re-interviewing other media's original sources professional journalists may seemingly avoid giving any credit to rivals, without fear of ethical or legal repercussions. Treading on colleagues' toes in this fashion happens with the rationale that any statement - new or old - from any source (typically contacted by telephone or e-mail) is by definition news. Especially TV, radio and the Internet increasingly cook source-broth from newspaper people's original ideas.

The current practices make most media operators dependent on easily accessible sources. The police, press secretaries and politicians know the journalists' operating conditions and news criteria, and these they may actively manipulate (Lund, 1999). Our data contains many instances where both routine material and solo stories have been pre-edited by people external to the media world. People in power with media know-how will concoct just the kind of bait that lemmings go for: uncomplicated cases with strong popular identification and a sensational element.

In this context it is thought-provoking to see just how diverse the citation practices of the Danish media are. In the edited society of the future, when the question of copyright law on creative products will surely be a hot potato, it should be appropriate to tighten up on source-critical ethics and faithful accreditation practices. The Internet has already shifted the boundaries between original and copy, substituting mutual inspiration with one-sided scrounging.

It would hardly do any harm to the credibility of TV stations to identify the morning dailies that present them with their evening news - free, gratis and for nothing. With present practices the suppliers of electronic news are undermining the journalists' ecosystem. The worst future scenario would be for the hard-pressed major suppliers, i.e. local, regional and national newspapers, to face close down due to unfair competition. This, indeed, may be the case unless more viable and profitable ways of combining print and new information technology shall be introduced into the journalistic foodchains.

The presentation-chain is the last and final link in the journalist's work-process. According to the textbooks of high quality journalism (Rich, 1997), presentation depend on ideas and sources. Most professionals agree that content is king, i.e. subject matter is more important than mere form. 
But the results from the research project at hand show that standard procedures are often turned upside down. "We've got a news-gap, how are we going to fill it?" (McManus, 1994).

In terms of presentation, $\mathrm{TV}$ is on top constantly marketing new journalistic formats, including tight controls, targeted planning and development of strategic concepts. Television news are more often than not schematically compiled according to a routinized schedule: A bit of hard news, something soft to round off, plus an expert on-screen via link sandwiched in between. This secures the profitable feel-good factor, but hardly produces originality and novelty in terms of the genealogy of news.

Add to this that TV and internet-services offer a steadily increasing number of news transmissions round the clock. There is, however, rarely a corresponding expansion of journalist staff, so in practice more slots to fill means that the reporting workforce is spread thinner and thinner over the day resulting in a less diversified week of news.

It is a lot easier (and cheaper) to update news material that has already been partially digested by other professionals, than to jump into the bewildering world out there and hunt for original material. In this context the grim reaper seems to be the Internet stealing stories from daily newspapers and news agencies (with or without attribution of the sources).

As a result of the technological advances in transmission and constant updating, to the audience it may well look as though the copy-cat is a far ahead of the original news provider - not only when it comes to breaking news. Where presentation and speed is king and queen, content becomes the pawn of the news game. On-line media may add fresh detail minute by minute and, like TV, bring the whole world into your home, live on screen. But as a net result fewer resources are available for investigative journalism in search for original news.

The ultimate, logical consequence of constant updating will be a permanent 'silly season'. The new technology opens up the possibility for constant re-working of a few events. This entails more recycling, and, consequently, less space for fresh news. In the unequal contest, the slow working media generating original ideas regularly go haywire. Like a lemming swarm, the daily papers head uncritically for the electronic serials. In so doing they themselves confirm to their sagging readers that the newspapers are being left hopelessly behind in the electronic hunt for news around the clock.

\section{Who Produce the News?}

Our research on One Week of Danish Journalism demonstrates that news providers live in a state of mutual interdependency. If a weakness develops at one point of the food-chains, it may lead to serious damage to other stages of the media ecosystem. The assembled data based upon unique combination of content analysis, interviews and observation has documented that news agencies and the daily newspapers occupy key positions in terms of genealogy of news. Media consumers, however, rate TV news more highly, and there are even higher expectations related to the Internet as the universal news medium of the future.

Most journalists and editors may regard such basic research points with a good deal of scepticism. Seasoned practitioners shall probably shake their heads with a "Well, we always knew that". Scepticism of this sort is healthy and not without justification. Redundant and roundabout research happens - in journalism studies too. But that makes it no less valid, just now and then, to stop and take stock of what the media are actually producing and how the everyday work of journalism translates into news. In terms of future prospects for professional journalism at least three important conclusions of political and practical import should be drawn from the data presented above:

First of all it is documented that public service in the field of news production is not primarily performed by traditional public service media such as licensed radio and television corporations. Commercially run newspapers provide the lions share of original news, i.e. public service for private money.

This, however, is not the impression of political decision makers in the field of media policy. In line with the majority of Danes, the Ministry of Culture regard public television as the most important provider of such services. Consequently, the Danish Parliament has been far more eager to subsidies electronic media that newspaper organizations, paradoxically arguing for such measures in terms of public interest in securing original and competitive news coverage.

In times of media convergence these trends have long term implications for content providers competing to become popular and high quality news sites on the national parts of the world wide web. It is vital that providers of original journalism get a fair deal in confrontation with the growing number of copy cats. Newscasting shall, no doubt, survive the coming convergence. But professional journal- 
ism may not necessarily remain the key provider of content as is already demonstrated by unscrupulous on line suppliers around the world.

Consequently, lack of knowledge and respect concerning the current genealogy of news may

\section{Note}

1. Case studies of this kind has been reported in Lund AB (red.). Forst med det sidste - en nyhedsuge $i$ Danmark. Århus: Forlaget Ajour, 2000.

\section{References}

Andersen E. et al. (1997) Ikke et ord om ytringsfrihed: Rapport om danske journalisters arbejde på danske dagblade. Århus: Modtryk.

Bakke M., Siune K. (1972) En uges radionyheder i Norden. Århus: Institut for Statskundskab.

Becker K. et al. (1996) Medierummet. Stockholm: Carlssons.

Boyd-Barrett, Rantanen T (eds) (1998) The Globalization of News. London: Sage.

Bruhn Jensen K. (ed.) (1998) News of the World. London: Routledge.

Ekecrantz J., Olsson T. (1990) Mellan makt och marknad. En studie $i$ nyhetsjournalistiken. Stockholm: Allmänna Förlaget.

Ekecrantz J., Olsson T. (1994) Det redigerade samhället. Om journalistikens, beskrivningsmaktens och det in formerade förnuftets historia. Stockholm: Carlssons.

Eliott P. (1992) The Making of a Television Series. London: Constable. threaten the very vitality of the journalistic foodchains - in spite of the fact that neither decision makers nor the general public live by discount reporting and moving pictures alone.

Hernes G. (1978) Det mediavridde samfunn. I: Forhandlingsфkonomi og blandingsadministrasjon. Oslo: Universitesforlaget, 181-95.

Hjarvad S. (1999) TV-nyheder i konkurrence. København: Samfundslitteratur

Høyer S. et al. (1982) Maktudredningen. Rapporten om massmedier. Oslo: Norges offentlige Utredninger 1982:30

Lund A.B. (1997) Smitsomme sygdomme i dansk journalistik. København: Munksgaard.

Lund A.B. (1999) "Journalist-roller i det redigerede samfund". Politica 31, 133-146.

McManus J.H. (1994) Market-Driven Journalism. London: Sage.

Nordstedt S.A (red.) (1994) En nyhedsdag: Svenska nyhetsredaktioners organisation, reportrar och uppdrag. Örebro: Högskolan i Örebro.

Petersson O., Carlberg I. (1990) Makten över tanken: En bok om det svenska massmediesamhället. Stockholm: Carlssons.

Rich C. (1997) Writing and Reporting News. New York: Wadsworth Publishing.

Sand G., Helland K. (1998) Bak TV-nyhetene: Produksjon og presentasjon i NRK og TV2. Bergen: Fagbokforlaget

Søllinge J.D. (1999) "Danish Newspapers - Structure and Development". Nordicom Review 1(1999)20, 31-76. 